Article

\title{
What Do We Mean by Sustainable Finance? Assessing Existing Frameworks and Policy Risks
}

\author{
Marco Migliorelli 1,2,+
}

1 European Commission, 1049 Brussels, Belgium; marco.migliorelli@ec.europa.eu

2 Sorbonne Business School, Université Paris 1 Panthéon-Sorbonne, 75013 Paris, France

+ The ideas presented in this paper do not necessarily reflect the official opinion of the European Commission.

\begin{abstract}
I observe that the sustainable finance landscape as it stands today is featured by an overabundance of heterogeneous concepts, definitions, industry and policy standards. I argue that such heterogeneity may hinder the smooth development of the conceptual thinking underpinning sustainable finance and originates specific risks that may harm the credibility of the nascent market. These risks include green and sustainable washing, the rebranding of financial flows without additionality, the disordered adjustment in the cost of capital spreads between industries. I argue that to reflect the actual industry and policy context as wells as to steer conceptual and applied practice sustainable finance should be today referred to as "finance for sustainability". To this extent, both its definition and implementing standards should make clear reference to the relevant sustainability dimensions (in particular in line with the Sustainable Development Goals and the Paris Agreement) and to the sectors or activities that positively contribute to these dimensions.
\end{abstract}

Keywords: sustainable finance; greenwashing; sustainable washing; rebranding; Sustainable Development Goals; Paris Agreement

check for updates

Citation: Migliorelli, M. What Do We Mean by Sustainable Finance? Assessing Existing Frameworks and Policy Risks. Sustainability 2021, 13, 975. https://doi.org/10.3390/su 13020975

Received: 15 December 2020

Accepted: 15 January 2021

Published: 19 January 2021

Publisher's Note: MDPI stays neutral with regard to jurisdictional claims in published maps and institutional affiliations.

Copyright: (C) 2021 by the author. Licensee MDPI, Basel, Switzerland. This article is an open access article distributed under the terms and conditions of the Creative Commons Attribution (CC BY) license (https:/ / creativecommons.org/licenses/by/ $4.0 /)$.

\section{Introduction and Summary}

Defining exhaustively sustainable finance, that is ensuring clarity on both its definition and implementing standards, is not an easy task. As a matter of fact, today an off-the-shelf, universal and workable definition of sustainable finance does not exist. Neither does it exist for the different families of sustainable finance securities, products or services available in the market. Guidelines have emerged and consolidated in the industry only for some key categories of securities (as green bonds and social bonds) and are considered effective but non-binding market references [1,2]. Thus far, financial institutions, governments, and international organisations have tended to create definitions according to their underlying motivations [3], resulting inter alia in a proliferation of heterogeneous terminology [4]. Region-wide policy initiatives to streamline and mainstream the sustainable finance market have been launched only recently [5] and are characterised by different perimeters and levels of ambition. Only little effort has been made to limit the issue of possible diverging interpretations of what sustainable finance is [6].

A flourishing of ambiguous definitions in what today can be considered the broader sustainable finance landscape has been noticed since long. Already two decades ago, environmental, social, and governance (ESG) investing could be described as an "area characterised by at best loose terminology, at worst by a conceptual confusion that would benefit from the rigour of academic analysis" [7]. Indeed, it is incumbent on academics to periodically reflect on the level and origins of conceptual fuzziness in their bodies of literature, as their disciplines evolve [8].

This paper aims at enriching the debate surrounding the issue of defining sustainable finance. To this extent, its contribution to the standing body of literature is twofold. On the one hand, it proposes a "workable" definition of sustainable finance, that is able to properly reflect the actual industry and policy context and specific enough to steer 
conceptual and applied practice. As a matter of fact, many of the existing definitions lack these characteristics and contribute to dilute research and industry efforts in explaining what sustainable finance means. This is done by building on the assessment of the key concepts, frameworks, and standards today featuring the sustainable finance industry, and their evolution over time. On the other hand, the paper identifies the main policy and financial risks stemming from defining sustainable finance, in particular in relation to the implementation of key operational standards, such as labels and taxonomies. From this basis, it is also possible to propose axes of action for policy makers in order to streamline the phasing-in of sustainable finance and shield the credibility of the nascent market (and related accountability practices).

I first argue that, on the basis of the observation of the current industry and policy context, sustainable finance should be today more coherently referred to as (be a synonym of) "finance for sustainability". In this respect, it should be considered as a self-standing factor in the effort to reach a sustainable society, in particular in line with the Sustainable Development Goals (SDG) and the Paris Agreement. Understanding today sustainable finance as "finance for sustainability" would represent a significant departure from its original meaning, when it could be more often referred (and limited) to the attempt to include sustainability-related considerations into investment decisions.

In this vein, a workable definition of sustainable finance should make clear reference to two intertwined issues, both intervening upstream and not pertaining specifically to the field of finance. The first is the identification of the possible sustainability dimensions. These are, but are not limited to, the preservation of the environment and the ecosystems, the conservation of the biodiversity, the fight against climate change, the eradication of poverty and hunger. The second is the assessment of the contribution of each economic sector or activity to the achievement of, or the improvement in, at least one of the relevant sustainability dimensions. This has to be done in order to identify the areas that deserve "sustainable" financing. Considering these two elements is sufficient to frame a workable definition of sustainable finance fitting with the actual industry and policy context. To this extent, sustainable finance could be defined as "finance to support sectors or activities that contribute to the achievement of, or the improvement in, at least one of the relevant sustainability dimensions".

This notwithstanding, to depict the complexity of the sustainable finance market as it stands today, a specific element should be given further attention. That is, the compliance of financial securities, products or services with one or the other of the several existing policy and industry frameworks, guidelines and related labels. To recognise the relevance of their specificity, these financial flows and stocks can be specifically referred to as "labelled sustainable finance". Labelled green, social and sustainable financial securities, products or services today represent the core component of the sustainable finance market (even if not the largest) and are particular relevant in steering market demand.

Finally, I argue that defining exhaustively sustainable finance should be a primary concern for policy makers. I recognise two main reasons why it has to be considered a critical factor in the process of consolidation of the market. First, uncertainties regarding what can be considered fully-fledged sustainable finance securities, products or services may undermine the confidence of the investors and discourage investment. In this respect, it is reasonable to assume that economic agents would consider sustainable finance as an option only if they are sure that their sustainability and values orientations are systematically reflected in the financial securities, products or services they are offered, with "no surprises". This issue can be analysed under the point of view of the emergence in the sustainable financial market of new information asymmetries and opaque information, and hence consequent possible opportunistic behaviours. The risks of greenwashing or sustainable washing or the possibility of mere refinancing of existing debt via labelled sustainable finance securities with no incremental resources directed towards sustainable investments (rebranding without additionality) are relevant examples. Second, on the basis of the specific sustainable finance framework in place, a progressive process of rebalancing of 
the investment portfolios may occur, in particular via the sell-off by institutional investors of securities of "non-sustainable" sectors and the purchase-and-hold of labelled sustainable finance or unlabelled securities pertaining to "sustainable" industries. This phenomenon may be accelerated by policy measures that may be launched to mainstream sustainable finance, such lower capital requirements for financial intermediaries holding sustainable finance securities, ad-hoc fiscal incentives for sustainable investments, or the inclusion of sustainability considerations in the central banks' monetary policy. Uncertainty on what should be considered sustainable finance can eventually contribute to trigger disordered pricing adjustments and a rapid increase in the differentials of both the cost of debt and equity between "sustainable" and "non-sustainable" industries, when changes in investors" expectations materialise.

The rest of the paper is structured as follows. Section 2 offers a narrative of the existing frameworks, definitions, and labelling standards that today feature the wider sustainable finance landscape. Section 3 deals with the construction of a workable definition of sustainable finance able to reflect the actual industry and policy context. In Section 4, the main risks stemming from defining sustainable finance are discussed, as well as their possible policy implications. Finally, Section 5 states concluding remarks and recalls the need for further debate on the topic.

\section{The Sustainable Finance Landscape: A Review of Existing Frameworks, Definitions and Labelling Standards}

The concern of the impact of economic activities on nature and social structures has been discussed for decades [9]. Through time, a number of possibilities to account for the connection between finance and sustainability have been proposed. Among them, it is possible to mention the rise of environmental, social and corporate governance (ESG) criteria in investment decision-making [10], the impact investing and the socially responsible investing (SRI) approaches [11], the concern with climate change and human rights [12], the assessment of the effect of finance in terms of negative externalities [13], or the role of sustainable finance for financial institutions already having a formal dual bottom-line approach and for which financial performance needs to coexist with social goals [14]. Moreover, in recent years, the sustainability landscape has been further shaped as following the landmark international agreements on the United Nations (UN) 2030 Agenda adopting the Sustainable Development Goals (SDG) and the Paris Agreement on climate action. In both these initiatives, the sustainability governance schemes and accountability patterns have put on finance an unprecedented attention and its role has been recalled as a key enabling factor for the attainment of the most ambitious sustainability-related objectives [9].

In the sub-sections that follow, I review the main frameworks, definitions, and labelling standards existing in the sustainable finance market. In this respect, I do not aim at providing a hermeneutic analysis of the all the possible definitions featuring the market (for this kind of exercise, focused on ESG literature, see for example [7]). Rather, I want to provide an extensive easy-to-understand description of the sustainable finance landscape and its funding principles as it stands today. This approach allows inter alia to propose two schematic representations that can be used to portray the sustainable finance market.

I conduct the review on the basis of three concentric layers of analysis, that is (from the largest to the smallest): (i) the wider policy context, (ii) the industry-originated frameworks, and (iii) the operational and labelling standards. As the layers are concentric, inner layers are coherent with larger ones in terms of scope but present specific and stricter characteristics. Figure 1 gives a representation of the sustainable finance landscape on the basis of these layers. 


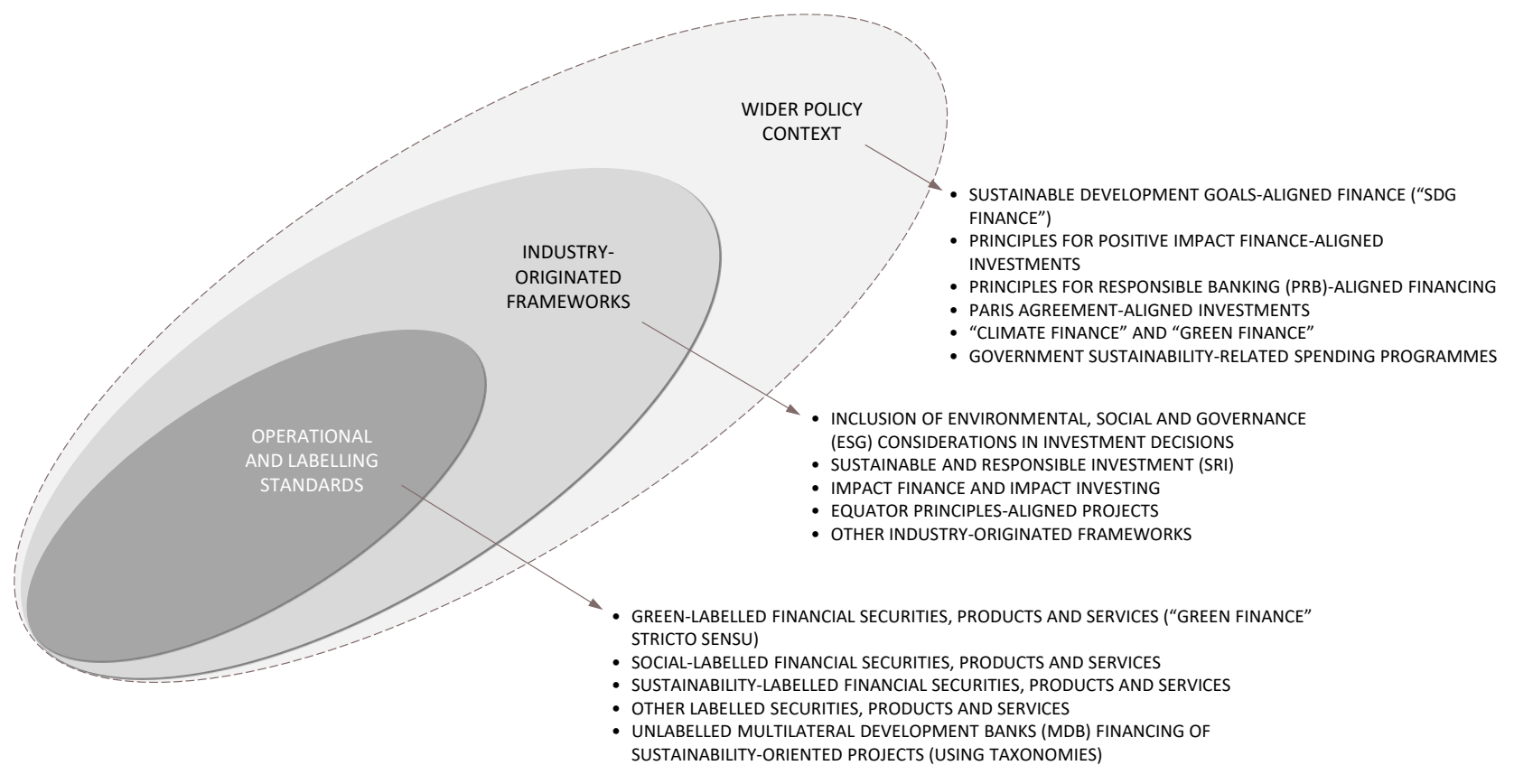

Figure 1. The sustainable finance landscape.

\subsection{Sustainable Finance and the Wider Policy Context}

The Sustainable Development Goals (SDG) and the Paris Agreement have landmarked the commitment of the international community towards a more sustainable society and a climate-neutral economy. To reach these ambitious objectives, a new technology framework, enhanced capacity-building, and a change in the consumption patterns were recalled as essential and nested elements, all needed to steer the transition. Nevertheless, to support such a transition, the mobilisation of financial resources has gained extraordinary attention [9]. Concerning the financing of the 17 SDG, several initiatives, mainly led by different $\mathrm{UN}$ bodies, have been launched in order to draw the main principles to direct the necessary flow of resources towards the goals and hence align global economic policies and financial systems with the 2030 Agenda. To this end, a total gap of USD 5-7 trillion worldwide a year until 2030 has been estimated [15]. Eventually, the concept of SDG finance has emerged. Enhancing sustainable financing strategies and investments at regional and country levels and seizing the potential of financial innovations, new technologies and digitalization to provide equitable access to finance are the main specific objectives underpinning this concept. In such a context, the Principles for Positive Impact Finance have been issued in 2017 within the Financial Initiative of the United Nations Environment Programme (UNEP-FI). They are guidelines for financiers and investors to increase their impact on the economy, society, and the environment, and aimed at providing basis for a common language across all categories of financial instruments and business activities [15]. Similarly, the Principles for Responsible Banking, focusing on banking operations, have been released in 2019 by the same body. These principles have the purpose to provide a general framework for a "sustainable" banking system in line with the SDG and the Paris Agreement, by embedding sustainability considerations at the banks' strategic, portfolio, and transactional levels, and across all business areas [16]. In parallel, the notions of Paris Agreement-aligned investments and, more general, green and climate finance have also emerged, these latter broadly referring to the financial resources necessary to support environmental objectives (green finance) and mitigation and adaptation actions that address climate change (climate finance) [9].

Against this background, concrete policy initiatives have been also launched worldwide in the attempt to mainstream the flow of resources directed towards sustainabilityrelated objectives. Probably, the most noteworthy example is represented by the European Union (EU). In the EU policy context, sustainable finance is defined as "finance to support 
economic growth while reducing pressures on the environment and taking into account social and governance aspects" and it is clearly understood to support the delivery of the "European Green Deal" by trying to channel private investment into the transition to a climate-neutral, climate-resilient, resource-efficient, and just economy [17]. To do that, the strategy of the European Commission builds on a specific Action Plan for sustainable finance [5] and follow-up initiatives.

The combination of abovementioned frameworks, concepts, and initiatives can indeed represent a first crucial, even though rather raw and generic, reference in the attempt to draw the (policy-driven) perimeter of action for sustainable finance. At this stage, without fixing any specific definition, sustainable finance may be indeed considered to first and foremost embrace the financial stocks and flows mobilised to achieve the SDG (SDG finance). Green finance and climate finance can be also considered specific components of sustainable finance. In this respect, green finance can be referred to as the financial stocks and flows aiming at supporting the achievement of the environment and climate-related SDG, while climate finance can be associated to that component of green finance focusing on climate action in line with the Paris Agreement objectives (in particular, in the form of climate change mitigation and climate change adaptation). However, to these broad categories it may be necessary to add as part of sustainable finance the financial stocks and flows directed to policy objectives that may not be covered by the SDG, but still have sustainability implications. Examples of these latter are the threats to sustainable development such as the weakening of democracy aided by "big technology," or the inferences of the fourth industrial revolution on the global workforce [18].

Figure 2 gives a visual representation of a policy-driven classification of the possible components of sustainable finance. As a matter of fact, such a wide scope, embracing the financing of the SDG, the Paris Agreement, and going even beyond, would result in considering sustainable finance as already a sizable and stable, but not yet completely visible, component of the modern financial system. In this regard, sustainable finance may in particular also encompass government spending programmes (eventually financed by unlabelled debt), when financing sustainability-related objectives.

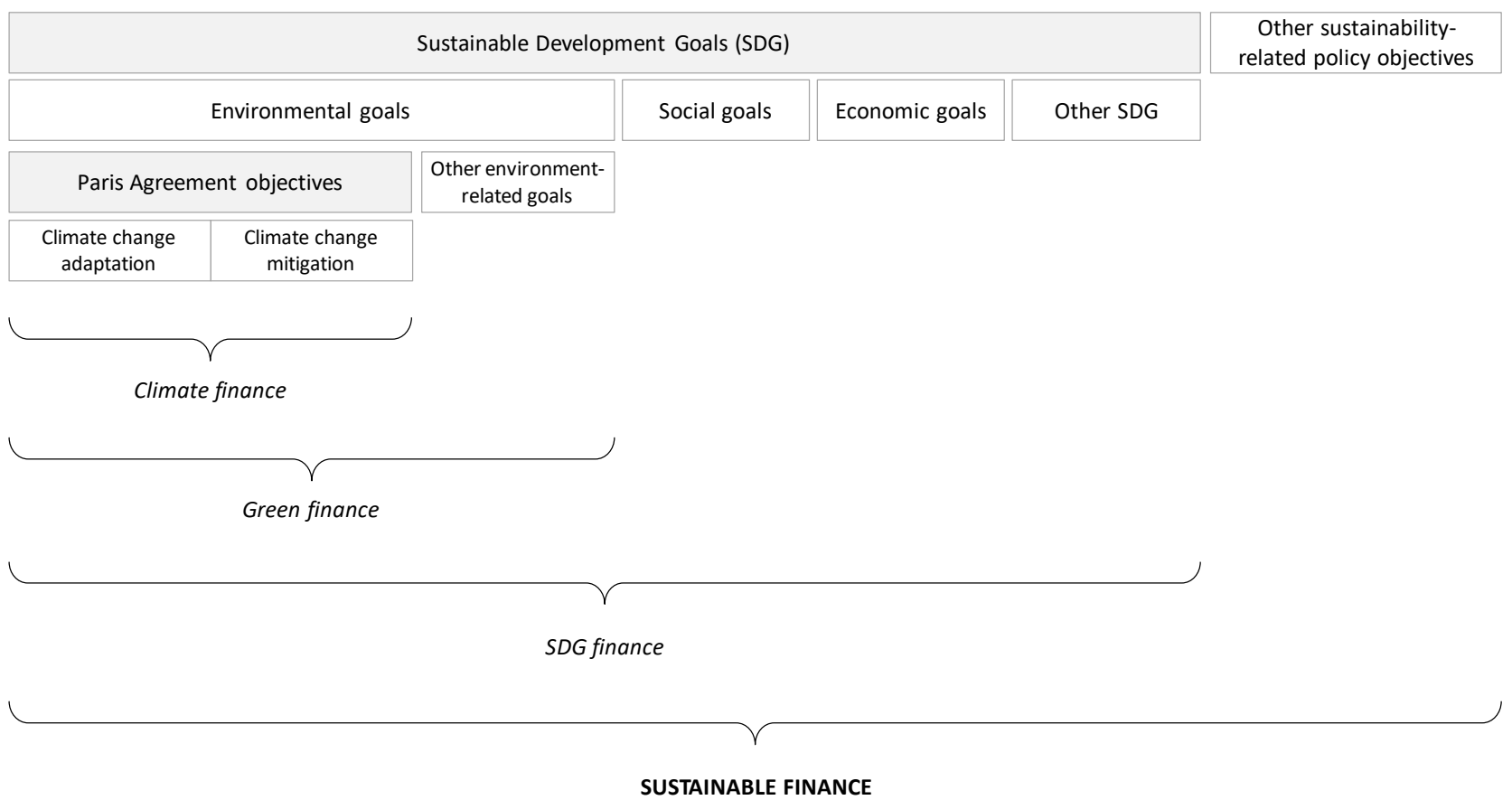

Figure 2. A policy-driven classification of sustainable finance and its main components. 


\subsection{Sustainable Finance and Industry-Originated Frameworks}

The financial industry has endogenously developed through time a number of frameworks that today should be considered to fully integrate the wider sustainable finance landscape. In some cases, these frameworks have seen the light much before the consolidation of the policy movement towards sustainability that can be observed in the last decade.

Likely, the most important example is represented by the inclusion of environmental, social, and governance (ESG) considerations in the investment decisions of financial actors. ESG have roots in not only faith-based investing, but also in the civil rights, anti-war, and environmental movements of the 1960s and 1970s $[9,19]$. However, in more recent years, the investment risks posed by climate change and poor corporate governance provided a huge catalyst in the growth of ESG investing [19]. In addition, disclosure of ESG information for financial and non-financial companies are increasingly demanded by policy makers in order to create a more transparent market and steer investors' decision-making. Noteworthy examples of ESG disclosure standards are the EU non-financial reporting directive (NFRD) or the voluntary guidelines developed by the climate disclosure project (CDP), the climate disclosure standards board (CDSB), the global reporting initiative (GRI), the principles for responsible investment (PRI), the sustainability accounting standards board (SASB) or the task force on climate-related financial disclosures (TCFD) [20].

Spreading instruments aimed to sustain investment decisions, providing information on the firm's position within a sustainability perspective jointly with financial information represents a newness both for people interested in ESG investments and for the entire plethora of stakeholders interested in the overall companies' performance [21,22]. An obvious consequence of these paradigm shifts is the felt need for strong support from institutional investors [23]. Within the carbon accounting literature, authors have identified two end-points on a spectrum of possible bases to deal with sustainability: accounting for un-sustainability and accounting for sustainability improvements [24]. The former aims to the disclosure of un-sustainable practices concerning past and current operations, and at predicting future levels of expected negative externalities (e.g., the level of GHG emissions). The latter informs about the decisions, and related measures, that a company is going to implement for improving its sustainable performance. Among these decisions and measures, the use of sustainable financing instruments probably represents one of the most effective, since it directly realizes the bridge between financial and natural capitals $[25,26]$. However, the growing interest of the industry in ESG performance may be also linked to the emergence of specific market incentives, related in particular to reputational gains and corporate social responsibility acknowledgement by existing and potential clients. As also observed in the literature, for a company to be recognised as engaged in sustainable activities it can bring concrete benefits in terms of customer satisfaction, customer retention, and market positioning [10,27].

Being today largely nested with ESG considerations, the concept of socially responsible investing (SRI) has also progressively spread in the financial industry. The basis for this contention revolves around the launch in 2006 of the United Nations-facilitated Principles for Responsible Investment (PRI) and the subsequent rise to prominence of this initiative among practitioners [28]. It refers to a voluntary set of investment principles that offer a set of possible actions for incorporating ESG issues into investment practices. More than a half of the total global institutional assets base are currently managed by institutions formally embracing these principles, demonstrating the commitment of financial markets towards ESG criteria within investment decisions [10].

ESG considerations and SRI do not certainly complete the financial industry-originated practices towards sustainability. Among the others, impact finance and the related impact investing should be first mentioned. Impact investments can be defined as "investments made with the intention to generate positive, measurable social and environmental impact alongside a financial return" [29]. This concept, in which the application can indeed span from social businesses to financial actors, in particular, focuses on the formal distinction between (and 
the co-existence of) financial and non-financial performances, with the aim to widen the final investment scope for market participants [30,31]. To this extent, impact investments can be made in both emerging and developed markets, and target a range of returns from below-market to market rate, depending on investors' strategic goals [29]. On the other hand, specifically concerning project management practices, the equator principles (EP) are emerging in recent years as a "financial industry benchmark for determining, assessing and managing environmental and social risk in projects" [32]. The EP may apply to all industry sectors and refer to five main financial products: project finance, project finance advisory services, project-related corporate loans, bridge loans, and project-related refinance and acquisition finance. In practice, the EP could already cover the majority of international project finance debt within both developed and emerging markets [32].

\subsection{Sustainable Finance and Operational and Labelling Standards}

When it comes to the observation of sustainable finance with regard to operational and labelling standards, the framework put in place for green bonds is by far the most advanced. This framework, endogenously developed within the financial industry, today benefits from a large acceptance of the green bond principles (GBP), issued by the International Capital Market Association (ICMA) in 2014 and then updated in 2018. The GBP are voluntary process guidelines that recommend transparency and disclosure and promote integrity in the development of the green bond market by clarifying the approach to be followed for the issuance of a green bond [1]. To this extent, green bonds are defined as "any type of bond instrument where the proceeds will be exclusively applied to finance or refinance, in part or in full, new and/or existing eligible green projects and which are aligned with the four core components of the GBP" [1]. The GBP then provide issuers with guidance on the four core components involved in launching a green bond, which are: use of proceeds, process for project evaluation and selection, management of proceeds and reporting. In practice, the framework provided by the GBP recommends a structured process for issuers, investors, banks, underwriters, and placement agents that can be used to appreciate the expected features of any given green bond [1]. The GBP also foresee issuers, in connection with the issuance of a green bond, to appoint at least one external reviewer to confirm the alignment of their bond with the four core components of the GBP (these external reviews can be of four types: second party opinions, verifications, certifications, or green bond scoring/ratings). Even though the GBP are not mandatory, their development has played thus far a significant role in structuring the green bonds market, providing all stakeholders with a tool able to effectively and easily segregate green bonds from other debt securities. In this respect, certification agencies acting as reviewers today make wide reference to the GBP in their assessment activity, in this way prompting a certain degree of homogeneity in the market. In 2019, a total of USD 257.7 billion green bonds was issued worldwide [33], representing a new record and confirming the double-digit growth of the market in recent years. Nevertheless, it should be argued that the green debt market can hardly be considered to be limited to instruments formally in line with the GBP and eventually labelled as green bonds. As a matter of fact, a not negligible part of the unlabelled bonds outstanding could in principle meet the criteria set by the GBP, even though the issuers eventually disregarded the labelling option (e.g., in the case of many municipal bonds issued to finance projects of water pollution prevention). The size of this market, which is very difficult to calculate with accuracy, is indeed expected to be at least twice as large as the labelled green bonds market standalone [33].

Following green bonds, labels were then proposed for social bonds [2] and sustainability bonds [34] with similar operational standards as green bonds but focused respectively on social and general sustainability goals, and sustainability-linked bonds [35], that novates by identifying a return to the investment for bond holders linked to the attainment of sustainability objectives measured by specific Key Performance Indicators (but, as intended to be used for general purposes, the use of proceeds for sustainability-linked bonds is not a 
determinant and leaves wide freedom to the issuer in deciding the type of investments to pursue).

Furthermore, labelling standards are progressively getting available for securities other than bonds, as it is the case for green loans [36], sustainability-linked loans [37], or the various types of sustainable funds. As a matter of fact, the fortune of these labelling standards will depend on their appeal in terms of steering market demand and on the incidence of administrative costs on the issuer. As these latter may be largely independent from the size of the operation, in many cases they may result in being too high to be attractive for operations of limited size [9].

Beyond labels, taxonomies represent today the essential operational standards in the sustainable finance market. Taxonomies, which are normally developed by multilateral development banks (MDB), financial industry organisations or policy makers, are lists that specify the sectors or the activities which are entitled to receive "sustainable" financing. In this respect, they are also used within the labelling frameworks mentioned above when it comes to analysing the use of proceeds [1,2]. Table 1 gives a general overview of the possible treatment of economic sectors and activities in existing sustainable finance taxonomies. Policy-wise, the most important initiatives launched to create taxonomies comprehend the EU Taxonomy of sustainable activities, in line with the mentioned Action Plan for sustainable finance [5] and the People Bank of China's Green Bond Endorsed Project Catalogue. However, as of today, these taxonomies have been principally developed for climate and (partially) environment-related investments, with little coverage of the possible other sustainability dimensions. Furthermore, today they are far from being homogeneous in terms of contents [6].

Table 1. Economic sectors or activities and treatment in existing sustainable finance taxonomies.

\begin{tabular}{|c|c|c|}
\hline \multirow[b]{2}{*}{ Main Category } & \multicolumn{2}{|c|}{ Treatment of the Sector or Activity in Existing Taxonomies } \\
\hline & Core Element & Possible Element \\
\hline \multicolumn{3}{|c|}{ Climate action } \\
\hline $\begin{array}{l}\text { Energy } \\
\text { production, } \\
\text { transmission, } \\
\text { and storage }\end{array}$ & $\begin{array}{ll}\text { - } & \text { Solar energy } \\
\text { - } & \text { Wind energy (in-shore and off-shore) } \\
\text { - } & \text { Geothermal energy } \\
\text { - } & \text { Small hydropower } \\
\text { - } & \text { Biomass energy } \\
\text { - } & \text { Storage systems } \\
\text { - } & \text { Smart grids and mini grids }\end{array}$ & $\begin{array}{ll}\text { - } & \text { Waste-to-energy systems } \\
\text { - } & \text { Cogeneration } \\
\text { - } & \text { Nuclear energy } \\
\text { - } & \text { Large hydropower } \\
\text { - } & \text { Bioenergy feedstock production } \\
\text { - } & \text { Clean coal } \\
\text { - } & \text { Cleaner fuel production } \\
\text { - } & \text { Improving efficiency of transmission systems }\end{array}$ \\
\hline Energy efficiency & $\begin{array}{ll}\text { - } & \text { Waste heat recovery } \\
\text { - } & \text { Industrial energy efficiency systems } \\
\text { - } & \text { Energy efficiency products }\end{array}$ & $\begin{array}{ll}\text { - } & \text { Energy efficient products } \\
\text { - } & \text { Energy efficiency in fossil fuel use }\end{array}$ \\
\hline Transport & $\begin{array}{ll}\text { - } & \text { Urban mass transit } \\
\text { - } & \text { Non-diesel railways }\end{array}$ & $\begin{array}{ll}\text { - } & \text { Electric and hybrid vehicles } \\
\text { - } & \text { Alternative fuel vehicles } \\
\text { - } & \text { Bicycle, pedestrian, waterways logistics } \\
\text { - } & \text { improvement } \\
\text { - } & \text { Riesel railways } \\
\end{array}$ \\
\hline Buildings & $\begin{array}{ll}\text { - } & \text { Building green retrofitting } \\
- & \text { New green buildings } \\
\text { - } & \text { Energy audits and energy services } \\
\text { - } & \text { Equipment improvement (e.g., lights, heating, } \\
& \text { ventilation, air conditioning) }\end{array}$ & $\begin{array}{l}\text { - } \quad \text { Advanced materials } \\
\text { Improvements/retrofitting/ } \\
\text { decommissioning of fossil fuels power plants }\end{array}$ \\
\hline $\begin{array}{l}\text { Agricultureand } \\
\text { land use }\end{array}$ & $\begin{array}{ll}- & \text { Energy and water saving } \\
\text { - } & \text { Afforestation and plantations } \\
\text { - } & \text { Reforestation }\end{array}$ & $\begin{array}{l}\text { - } \quad \text { Conservation agriculture } \\
\text { - } \quad \text { Ecotourism }\end{array}$ \\
\hline
\end{tabular}


Table 1. Cont.

\begin{tabular}{|c|c|c|}
\hline \multirow[b]{2}{*}{ Main Category } & \multicolumn{2}{|c|}{ Treatment of the Sector or Activity in Existing Taxonomies } \\
\hline & Core Element & Possible Element \\
\hline $\begin{array}{l}\text { Non-energy } \\
\text { greenhouse gases } \\
\text { (GHG) emissions }\end{array}$ & $\begin{array}{ll}\text { - } & \text { Coal mine methane capture } \\
\text { - } & \text { Carbon capture and storage (CCS) } \\
\text { - } & \text { Reduction in GHGs (e.g., in cement or chemicals) }\end{array}$ & - \\
\hline $\begin{array}{l}\text { Disaster } \\
\text { prevention and } \\
\text { economic } \\
\text { resilience }\end{array}$ & - & $\begin{array}{ll}- & \text { Climate resilient infrastructures } \\
- & \text { Early warning systems } \\
\text { - } & \text { Insurance against natural disasters }\end{array}$ \\
\hline $\begin{array}{l}\text { Other sectors } \\
\text { with possible } \\
\text { implications on } \\
\text { climate action }\end{array}$ & - & $\begin{array}{ll}\text { - } & \text { Broadband } \\
\text { - } & \text { Data centres using renewable energy } \\
\text { - } & \text { Low carbon energy-powered mobile base } \\
& \text { stations } \\
\text { - } & \text { Virtual conferencing and tech substitution }\end{array}$ \\
\hline \multicolumn{3}{|c|}{ Environmental sustainability } \\
\hline $\begin{array}{l}\text { Environment } \\
\text { protection }\end{array}$ & $\begin{array}{ll}\text { - } & \text { Protection of biodiversity } \\
\text { - } & \text { Protection of seas } \\
\text { - } & \text { Sustainable forest management }\end{array}$ & $\begin{array}{ll}\text { - } & \text { Sustainable fisheries } \\
\text { - } & \text { Identification of protected ecosystems }\end{array}$ \\
\hline $\begin{array}{l}\text { Pollution control } \\
\text { and waste } \\
\text { management }\end{array}$ & $\begin{array}{ll}\text { - } & \text { Air/water pollution control } \\
\text { - } & \text { Soil remediation and mine rehabilitation } \\
\text { - } & \text { Waste gasification } \\
\text { - } & \text { Composting } \\
\text { - } & \text { Recycling }\end{array}$ & $\begin{array}{l}\text { - Landfill and incineration of waste without } \\
\text { energy or gas capture }\end{array}$ \\
\hline $\begin{array}{l}\text { Water } \\
\text { management }\end{array}$ & - Water saving & $\begin{array}{ll}\text { - } & \text { Municipal water management } \\
\text { - } & \text { Industrial and agricultural water supply } \\
\text { - } & \text { Treatment of wastewater to meet compliance } \\
\text { obligations }\end{array}$ \\
\hline
\end{tabular}

Social development and social equality

\begin{tabular}{|c|c|c|}
\hline $\begin{array}{l}\text { Basic social } \\
\text { infrastructures }\end{array}$ & $\begin{array}{ll}\text { - } & \text { Clean drinking water } \\
\text { - } & \text { Access to sanitation } \\
\text { - } & \text { Hospitals and basic healthcare } \\
\text { - } & \text { Education and vocational training } \\
\text { - } & \text { Essential financial services } \\
\text { - } & \text { Affordable and social housing }\end{array}$ & $\begin{array}{l}\text { - Programmes of support to private } \\
\text { microfinance initiatives }\end{array}$ \\
\hline $\begin{array}{l}\text { Decent } \\
\text { employment }\end{array}$ & $\begin{array}{l}\text { - } \quad \text { Employment generation for target population } \\
\text { - } \quad \text { Upskilling and reskilling of vulnerable population } \\
\text { - } \quad \text { Decent salary } \\
\text { Programmes to alleviate unemployment following } \\
\text { socioeconomic crises }\end{array}$ & $\begin{array}{l}\text { - } \quad \text { General employment generation } \\
\text { - } \quad \text { Salary support schemes }\end{array}$ \\
\hline $\begin{array}{l}\text { Reduction of } \\
\text { inequalities }\end{array}$ & $\begin{array}{l}\text { - } \quad \text { Programmes to support gender equality } \\
\text { - } \quad \text { Programmes to fight sexual discrimination } \\
\text { - } \quad \text { oquitable access to assets, services, resources, and } \\
\text { - } \quad \begin{array}{l}\text { Equitable participation and integration into the } \\
\text { market and society }\end{array}\end{array}$ & $\begin{array}{ll}\text { - } & \text { Positive discrimination } \\
\text { - } & \text { Reduction in income inequalities } \\
\text { - } & \text { Equality on other grounds }\end{array}$ \\
\hline $\begin{array}{l}\text { Food security } \\
\text { and sustainable } \\
\text { food systems }\end{array}$ & $\begin{array}{l}\text { - } \quad \text { Physical, social, and economic access to safe nutrition } \\
\text { - } \quad \text { Sufficient food that meets dietary needs } \\
\text { - } \quad \text { Resilient agricultural practices } \\
\text { - } \quad \text { Reduction of food loss and waste } \\
\text { - Improvement in productivity of small-scale producers }\end{array}$ & $\begin{array}{l}\text { - General improvement in agricultural output } \\
\text { or productivity }\end{array}$ \\
\hline
\end{tabular}

Author's elaboration on $[1,2,6,38]$. Core element means that the sector or activity is commonly included in the main existing sustainable finance taxonomies. Possible element means that the sector or activity is included in some of the existing taxonomies or is a debated element. The table does not aim to be exhaustive. 


\section{A Definition of Sustainable Finance}

It can be argued that the meaning attached to sustainable finance has evolved over time. In a retrospection of its early days, that can be broadly brought back to the rise of ESG concept, sustainable finance largely meant that the financial system should incorporate sustainability considerations in investment decision-making, in order to better reflect environmental and other sustainability-related risks. With the evolution in the societal and policy patterns, the meaning of sustainable finance has progressively consolidated around the need to provide sufficient financial resources to the transition towards a more sustainable society and a climate-neutral economy. This (incremental) shift in perspective may also help explain the observed acceleration, in recent years, in the adoption of sustainable finance practices by financial institutions.

In this vein, I argue that coherently defining sustainable finance requires today the comprehension of two intertwined elements. The first is the identification of the concrete sustainability dimensions. In practice, this means answering the question: What is sustainability? Even though also in this case an universal answer may not be readily available, it can be easily stated that there is little incertitude about including among the relevant sustainability dimensions the preservation of the environment and the ecosystems, the conservation of the biodiversity, the fight against climate change (in particular in the form of climate change mitigation and climate change adaptation), the eradication of poverty and hunger, the reduction of inequalities. In this respect, it should be agreed that the SDG and the Paris Agreement have arisen in recent years as key (policy-driven) initiatives to forge the perimeter of sustainability, being also able to steer at a larger extent recent financial industry developments. This is true even though it can be argued that these initiatives do not consider some possible sustainability dimensions.

The second element to consider in developing a definition of sustainable finance is the contribution of each economic sectors or activity to the achievement of, or the improvement in, one or more of the relevant sustainability dimensions. This has to be done in order to identify the areas that deserve "sustainable" financing. This reasoning can be brought back to answer the question: How can sustainability be reached? If some sectors or activities are unanimously considered as contributing to sustainability (e.g., in the case of renewable energy projects or initiatives for the access to sanitation in developing countries), for others this assessment may still not be straightforward (e.g., in the case of nuclear energy, a low-carbon energy source, or incentives for facilitating the access to higher education in developed countries).

I argue that answering these two questions is sufficient to frame a workable definition of sustainable finance, which is able both to reflect the actual industry and policy context and steer conceptual and applied practice. To this extent, sustainable finance can be defined as "finance to support sectors or activities that contribute to the achievement of, or to the improvement in, at least one of the relevant sustainability dimensions". As a matter of fact, the proposed definition of sustainable finance does not aim at redefining "finance", which is a concept factored-in as an input. Indeed, it focuses on the recognition of the role of finance in supporting sustainability. On this basis, sustainable finance could be today also referred to as (and is a synonym of) "finance for sustainability".

The proposed definition is workable as it explicitly refers to the need for an analysis upstream of both the relevant sustainability dimensions (What is sustainability?) and the sectors and activities that have a positive impact on such dimensions (How can sustainability be reached?). In this respect, it should be underlined that the taxonomies that today exist, even if a heterogeneity of approach and perimeters, mainly follow this line or reasoning and are indeed useful tools in order to systematize knowledge on what should be considered eligible for "sustainable" financing. Furthermore, it can be highlighted that via the proposed definition of sustainable finance no considerations are made on whether or not finance can be considered by itself a sustainable activity (in this sense again largely reflecting the current industry and policy practice). 
This apart, when proposing a given definition of sustainable finance, an addition element should be specifically considered in order to face the complexity of the market. It refers to the compliance of financial flows and stocks (via financial securities, products or services) with one or the other of the several policy and industry frameworks, guidelines and related labelling standards that feature the sustainable finance landscape. This aspect may be linked to the question: How can sustainable finance be easily recognised? In this respect, the methodologies that have been progressively proposed have mainly aimed to attract the investors' appetite towards new products categories via new labels. In point of fact, labelled green, social and sustainable financial securities, products or services today represent the core component of the sustainable finance market and the one which is more easily identifiable. In order to highlight the relevance of this specificity, the ensemble of these financial instruments can be referred to as "labelled sustainable finance". As of today, labelled sustainable finance plays a particularly relevant role in steering market demand.

In this general framework, an argument can be made accordingly to the idea that it is the joint responsibility of policy makers and the scientific community to define which are the relevant "sustainability dimensions" and the "sectors or activities that contribute to the achievement of, or the improvement in, at least one of the relevant sustainability dimensions". Furthermore, it is in the remit of policy makers and the financial industry defining coherent frameworks, guidelines, and labelling standards for sustainable financial instruments. Finally, it should be in the mission of financial institutions to mainstream sustainable finance.

Lastly, a degree of freedom should be recognised to sustainable finance. As scientific knowledge progresses and societal sensitivity towards certain issues may evolve over time, what today could be considered as "sustainability dimensions" and "sectors and activities that contribute to the achievement of, or the improvement in, at least one of the relevant sustainability dimensions" may also change. Even though the proposed definition of sustainable finance may still hold, it is in the hands of policy makers to manage these possible shifts, the main paradigm remaining constant.

\section{Main Risks Stemming from Defining Sustainable Finance}

Coherently defining sustainable finance, by ensuring clarity on its definition as well as its implementing standards, is not a mere exercise of style. On the contrary, a wellconceived identification of sustainable finance represents a key enabler in the development of the market. In this section, I aim at identifying the main risks stemming from defining sustainable finance (in particular with reference to labels and taxonomies) and their possible policy and financial implications, as well as at proposing policy actions to reduce the incidence of these risks.

\subsection{Rebranding without Additionality}

A first risk linked to defining sustainable finance concerns labelled sustainable finance and its role within the wider sustainable finance landscape. Labelled sustainable finance has experienced an exceptional growth in recent years. In this respect, Figure 3 shows the level of labelled green bonds issuance since the inception of the market. However, such a growth does not necessarily mean that the investments flow towards "sustainable" sectors or activities have increased at the same pace. It is indeed reasonable to argue that the growth rate experienced in the market of labelled sustainable finance securities, products, and services is considerably higher than the growth rate of the overall stream of investments in "sustainable" sectors or activities. 


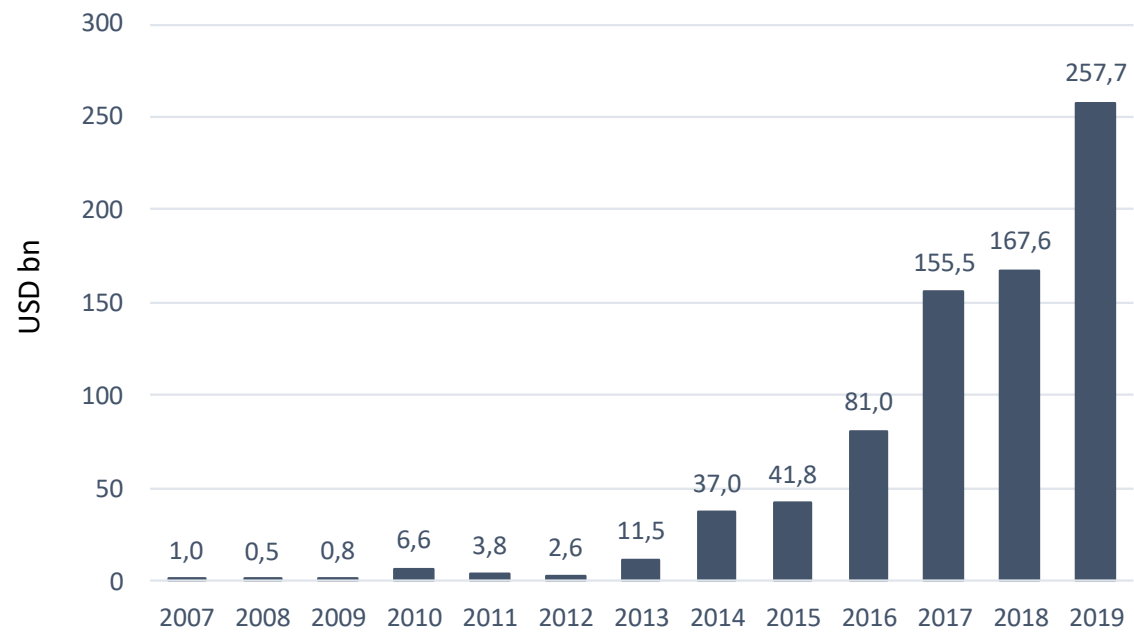

Figure 3. Level of green bonds issuance since the inception of the market. Author's elaboration on data Climate Bonds Initiative (CBI), Bloomberg and European Investment Bank. Values refer to labelled securities. They include green bonds and green asset-based securities (ABS).

As a matter of fact, a certain level of rebranding of financial flows may have featured the market thus far and it is likely to remain in the near future. In this respect, labelled debt from refinancing operations, labelled government debt for green or social projects, newly labelled debt of pure players in the renewable energy sector, or green labelled debt issued by financial intermediaries are among the financing operations which are likely to provide little additional resources to the transition to a more sustainable society. Similarly, several labelled "sustainable", "social" or "green" funds may also suffer from similar limitations in their sustainability imprint, for example, when considering that already in 2015 about $50 \%$ of the institutional assets base were managed by institutions formally endorsing the Principles for Responsible Investment [10].

As a matter of fact, rebranding is up to a certain extent physiological in a market which is still a promising niche and far from becoming mainstream. Nevertheless, two main risks on the nascent market should be highlighted concerning the possible lack of additionality of labelled financial flows. On the one hand, investors may start perceiving that "no real impact" is triggered when buying labelled sustainable securities, products and services, resulting in a progressively lower market appeal. This may be particularly true for retail customers after the completion of the phase of first expansion of the market. On the other hand, policy makers may misjudge the effectiveness of the measures they have put in place to foster a more sustainable society or mainstreaming sustainable finance if over-relying on the growth of labelled sustainable finance.

To ease this problem, an improvement of disclosure requirements and standards may indeed play a decisive role. In particular, non-financial disclosure at the corporate level having as an object sustainability performance may incorporate a dimension linked to effective additionality. In practice, additionality could be disclosed with respect to a specified reference period in the past (e.g., 5 years or the beginning of the most recent strategic plan) or over time (e.g., in the last 10 years). In this vein, an increase in the level of labelled sustainable finance issued may be contextualised within the discourse around additionality at a single organisation-level. On the other hand, the assessment of effective additionality may benefit from statistics and historical series on the level of investments in "sustainable" sectors and activities at a national or regional level. This could be eventually done in line with a defined taxonomy of "sustainable" activities. In this way, it would be possible to provide easily accessible information to policy makers and other stakeholders on the level of additional resources directed over time towards sustainability-related objectives. 


\subsection{Greenwashing and Sustainable Washing}

Simultaneously to the development of the sustainable finance and the rise of related certifications and reviews, the discussion on whether financial actors can use deceptive strategies to promote their securities, products, and services, and build a sustainabilityoriented image is also emerging. This phenomenon had first concerned environmental performances and policies, and is commonly known as "greenwashing". It has recently expanded to the entire sustainability spectrum, featured as "sustainable washing".

Greenwashing and sustainable washing are not specific to sustainable finance, and first appeared in the consumer goods industry. In this respect, the literature has already observed that greenwashing or sustainable washing can take many forms, ranging from changing the name of a product to inducing the perception that it comes from a natural environment to the launch of marketing campaigns by polluting industries in order to foster a sustainable-friendly image [39,40]. The same body of literature has also noticed that given the increase in the awareness in the society regarding the potential sustainability impacts of the products purchased, formal or informal labelling (such as "green", "ecofriendly" or "sustainable") are getting increasingly effective in driving market demand. Consequently, it has been observed how many products have been benefiting from a form of advertising even though the claims put forward did not present the real characteristics of the product [41,42].

The risk of greenwashing and sustainable washing is progressively consolidating in the sustainable finance market. As a matter of fact, the lack of universal definitions and standards amplifies such a risk as it opens to several possible interpretations of what sustainability means in the financial markets. For this reason, as the market for sustainability-related certifications and reviews continues to develop, regulation on the communication regarding the sustainability impact of financial securities, products, and services marketed as sustainable should be also expected to become stricter. Again, clarity on the relevant sustainability dimensions and the sectors and activities that deserve "sustainable" financing is a first step. Therefore, stricter labelling standards and disclosure requirements (at a level of issuance) would further strengthen the reliability of existing market references.

\subsection{Disordered Adjustment in Cost of Capital Spreads}

Sustainable finance can impact directly on both the cost of capital and the cost of equity of "non-sustainable" sectors via a demand-driven redirection of financial flows towards "sustainable" industries. On the basis of the specific sustainable finance framework put in place (in particular, concerning its industry standards such as labels and taxonomies), a process of rebalancing of the investment portfolios may occur in the market. This may take the form of a progressive sell-off by institutional investors of securities of "non-sustainable" companies and the purchase-and-hold of labelled sustainable finance or unlabelled securities of industries considered to be sustainable. In this respect, some early evidence has been already produced by scientific literature, in particular, concerning differences in yields between green bonds and corresponding conventional bonds [43]. A green bond premium (or greenium) may progressively consolidate in the financial market, underlying the role of labelled sustainable finance in shaping market investors' preferences.

This dynamic could be further strengthened in the near future by policy measures aiming at mainstreaming sustainable finance, such as in the case of lower capital requirements for financial intermediaries holding sustainable finance securities, ad-hoc fiscal incentives for sustainable investments, or the inclusion of sustainability considerations in the central banks' monetary policy [20].

Uncertainty on what should be considered sustainable finance can eventually contribute to trigger disordered pricing adjustments and result in a sharp and significant increase in the differentials of both the cost of debt and equity between "sustainable" and "non-sustainable" industries, in case changes in market expectations materialise. 
The possible policy actions to mitigate the risk of disordered pricing adjustments between "sustainable" and "non-sustainable" industries are manifold. These may include performing ex-ante and ex-post impact assessments for the measures aiming at fostering sustainable finance, introducing reliable "transition" labels for securities aiming at encouraging reconversion of polluting industries, or establishing policy frameworks to manage sustainability-related financial risks both at the systemic and company level [20].

This issue may be also further investigated in relation to the emergence of stranded assets. Stranded assets can be defined as "assets that have suffered unanticipated or premature write-downs, devaluations, or conversions to liabilities" [44], and may become particularly relevant in the context of transition to a low-carbon economy $[45,46]$. Policy and technology shifts that may follow the identification of sectors and activities that contribute to reach a "sustainable" society (in these terms also relevant in the context of defining sustainable finance) are expected to be the main triggers of stranded assets $[47,48]$. In this respect, measures to encourage the low-carbon transition may take several forms, such as ad-hoc fiscal incentives [49], public support schemes to investments [50], or stricter environmental regulatory requirements [51]. Even though the occurrence of stranded assets principally pertains to the possible paths towards sustainability more than to the field of finance, financial flows directed via sustainable finance still have the potential to accelerate the necessary adjustments and ignite financial risks [52,53].

\subsection{Differences between Jurisdictions in Labels and Operational Standards}

Financial markets are nowadays widely globalised, and financial securities are easily tradable worldwide within minutes. On the contrary, the initiatives to steer or even mainstream sustainable finance have had thus far a national or regional scope, without significant efforts made at the international level to harmonise the different approaches. When it comes to labelling standards, there is today the concrete risk that securities having a similar label (e.g., green bonds) eventually may not meet the same requirements, in particular, in terms of the use of proceeds. As a concrete example, the Chinese Green Bond Endorsed Project Catalogue accepts as eligible activities the retrofits of fossil fuel power stations, clean coal and coal efficiency improvements, or rail lines that transport fossil fuels. These activities are normally not present in similar taxonomies developed in Europe.

Such heterogeneity may indeed jeopardise the interest of investors and create uncertainty in a globalised financial market. Policy-wise, two main axes of action may be envisaged to limit the incidence of this issue. On the one side, initiatives at the international level may be launched in order to steer harmonisation in financial labels and other operational standards. This could be done within the existing fora such as the network for greening the financial system (NGFS). On the other side, reliable, synthetic, and easily accessible information on differences between several standards should be made available to market investors (e.g., at a level of stock exchanges) in order to allow proper decisionmaking at the moment of buying labelled sustainable finance. As a matter of fact, the need of an effective transnational governance regime of sustainable finance can no longer be postponed or put off. Indeed, it should follow the same trends observed for global wicked issues as climate change [54-56].

\section{Concluding Remarks}

The path towards the achievement of a sustainable society and a climate-neutral economy encompasses different disciplines. Effective regulation, technological improvements, scientific research, and changes in consumption patterns have been considered for many years the main engines of the transition. However, finance has recently arisen as an essential enabling factor, capable of having a concrete impact on the feasibility and the speed of the changeover. In this context, the notion of sustainable finance has emerged to catalyse the financial efforts of policy makers, financial industry, and civil society in reaching sustainability. 
This notwithstanding, I noticed that the sustainable finance landscape as it stands today still suffers from a certain degree of conceptual incertitude. This is mainly due to the overabundance of frameworks, definitions, and labelling standards that have been created over time and have contributed to dispersing conceptual thinking on the matter. This heterogeneity may indeed dilute policy and industry efforts to streamline and mainstream sustainable finance, by triggering specific financial and policy risks. Table 2 summarizes these risks and the consequent possible mitigating policy actions, as discussed along the paper.

Table 2. Risks linked to defining sustainable finance, possible negative effects, and possible policy actions to mitigate the risks.

\begin{tabular}{|c|c|c|}
\hline Risk & Possible Negative Effect & Possible Policy Actions to Mitigate the Risk \\
\hline $\begin{array}{l}\text { Rebranding } \\
\text { without } \\
\text { additionality }\end{array}$ & $\begin{array}{l}\text { - Lessening of investors' confidence in the } \\
\text { market and consequent sub-optimal resource } \\
\text { allocation to "sustainable" sectors } \\
\text { Dilution of policy action in case of } \\
\text { overreliance on labelled sustainable finance to } \\
\text { reach sustainability-related policy objectives }\end{array}$ & $\begin{array}{l}\text { - Disclose additionality at the corporate level } \\
\text { Publish national or regional-level statistics on } \\
\text { investments in "sustainable" sectors or activities } \\
\text { (eventually on the basis of a taxonomy) }\end{array}$ \\
\hline $\begin{array}{l}\text { Greenwashing and } \\
\text { sustainable } \\
\text { washing }\end{array}$ & $\begin{array}{l}\text { - Lessening of investors' confidence in the } \\
\text { market and consequent sub-optimal resource } \\
\text { allocation to "sustainable" sectors }\end{array}$ & $\begin{array}{l}\text { - Identify sectors and activities eligible for } \\
\text { "sustainable" financing (e.g., via a taxonomy) } \\
\text { - } \quad \text { Define clear labelling standards } \\
\text { - Identify disclosure standards for labelled securities }\end{array}$ \\
\hline $\begin{array}{l}\text { Disordered } \\
\text { adjustment in cost } \\
\text { of capital spreads }\end{array}$ & $\begin{array}{l}\text { - Sharp increase in the cost of equity and debt } \\
\text { for "non-sustainable" industries } \\
\text { - Acceleration in economic and financial losses } \\
\text { for "non-sustainable" industries }\end{array}$ & $\begin{array}{l}\text { - Perform ex-ante and ex-post impact assessments } \\
\text { of measures aiming at supporting sustainable } \\
\text { finance } \\
\text { - Introduce "transition" labels for financial } \\
\text { securities aiming at financing the reconversion of } \\
\text { polluting industries } \\
\text { Put in place specific policy frameworks to } \\
\text { manage sustainability-related financial risks (at } \\
\text { the systemic and company level) }\end{array}$ \\
\hline $\begin{array}{l}\text { Differences } \\
\text { between } \\
\text { jurisdictions in } \\
\text { labels and } \\
\text { operational } \\
\text { standards }\end{array}$ & $\begin{array}{l}\text { - Lessening of investors' confidence in the } \\
\text { market and consequent sub-optimal resource } \\
\text { allocation to "sustainable" sectors }\end{array}$ & $\begin{array}{l}\text { Promote international initiatives aiming at } \\
\text { harmonising financial labels and other } \\
\text { operational standards in sustainable finance } \\
\text { Provide investors with reliable, synthetic, and } \\
\text { easily accessible information on the differences } \\
\text { between jurisdictions in labels and operational } \\
\text { standards (eventually at a level of } \\
\text { stock exchanges) }\end{array}$ \\
\hline
\end{tabular}

This paper represents a concrete step in the direction of fostering a deeper understanding of what sustainable finance means in the actual industry and policy context and what are the related main policy and financial risks as the market develops. In this respect, I argue that bringing sustainable finance to the notion of "finance for sustainability" is an effective way to reflect the complexity of the market as it stands today and steer both theoretical conceptualisation and industry practice. In this vein, a definition of sustainable finance should be framed in a way to clearly refer to the debate on the identification of the relevant sustainability dimensions and of the sectors or activities that effectively contribute to these dimensions. Labels and taxonomies should be created along this pattern with the aim to ensure clarity to market investors.

However, further academic research and discussion seem to be needed as concerns both the definition of sustainable finance and the related implementing standards. For this reason, a call for further work has to be made in order to consolidate a way of thinking or propose alternative venues of reasoning. 
Funding: This research received no external funding.

Informed Consent Statement: Not applicable.

Conflicts of Interest: The author declares no conflict of interest.

\section{References}

1. International Capital Market Association (ICMA). Green Bond Principles. In Voluntary Process Guidelines for Issuing Green Bonds; International Capital Market Association: Zurich, Switzerland, 2018.

2. International Capital Market Association (ICMA). Social Bond Principles. In Voluntary Process Guidelines For Issuing Social Bonds; International Capital Market Association: Zurich, Switzerland, 2020.

3. International Finance Corporation (IFC). Green Finance: A Bottom-up Approach to Track Existing Flows; International Finance Corporation (IFC): Washington, DC, USA, 2017.

4. Forstater, M.; Zhang, N.N. Definitions and Concepts: Background Note; UNEP Inquiry: Nairobi, Kenya, 2016.

5. European Commission (EC). Action Plan: Financing Sustainable Growth; European Commission (EC): Brussels, Belgium, 2018.

6. European Investment Bank (EIB). The Need for a Common Language in Green Finance; European Investment Bank (EIB): Kirchberg, Luxembourg, 2017.

7. Sparkes, R. Ethical investment: Whose ethics, which investment? Bus. Ethics Eur. Rev. 2001, 10, 194-205. [CrossRef]

8. Eccles, N.S.; Viviers, S. The origins and meanings of names describing investment practices that integrate a consideration of ESG issues in the academic literature. J. Bus. Ethics 2011, 104, 389-402. [CrossRef]

9. Migliorelli, M.; Dessertine, P. The Rise of Green Finance in Europe: Opportunities and Challenges for Issuers, Investors and Marketplaces; Palgrave Macmillan: London, UK, 2019.

10. Friede, G.; Busch, T.; Bassen, A. ESG and financial performance: Aggregated evidence from more than 2000 empirical studies. J. Sustain. Financ. Invest. 2015, 5, 210-233. [CrossRef]

11. Hebb, T. Impact investing and responsible investing: What does it mean. J. Sustain. Financ. Invest. 2013, 3, 71-74. [CrossRef]

12. Alm, K.; Sievänen, R. Institutional investors, climate change and human rights. J. Sustain. Financ. Invest. 2013, 3, 177-183. [CrossRef]

13. Ziolo, M.; Filipiak, B.Z.; Bąk, I.; Cheba, K.; Tîrca, D.M.; Novo-Corti, I. Finance, sustainability and negative externalities: An overview of the European context. Sustainability 2019, 11, 4249. [CrossRef]

14. Migliorelli, M. Cooperative Banking in Europe Today: Conclusions; Migliorelli, M., Ed.; Palgrave Macmillan: London, UK, 2018.

15. United Nations Environment Programme-Financial Initiative (UNEP-FI). The Principles for Positive Impact Finance: A Common Framework to Finance the Sustainable Development Goals; United Nations Environment Programme-Financial Initiative (UNEP-FI): Nairobi, Kenya, 2017.

16. United Nations Environment Programme-Financial Initiative (UNEP-FI). Principles for Responsible Banking; United Nations Environment Programme-Financial Initiative (UNEP-FI): Nairobi, Kenya, 2019.

17. European Commission (EC). The European Green Deal; European Commission (EC): Brussels, Belgium, 2019.

18. Peterson, G.; Yawson, R.; Ellen, J.K.; Nicholls, J. Navigating Big Finance and Big Technology for Global Change: The Impact of Social Finance on the World's Poor; Palgrave Macmillan: London, UK, 2020.

19. Townsend, B. From SRI to ESG: The origins of socially responsible and sustainable Invest. J. Impact ESG Invest. 2020, 1, 10-25. [CrossRef]

20. Migliorelli, M.; Dessertine, P. Sustainability and Financial Risks: The Impact of Climate Change, Environmental Degradation and Social Inequality on Financial Markets; Palgrave Macmillan: London, UK, 2020.

21. Andrew, J.; Cortese, C. Accounting for Climate Change and the Self-Regulation of Carbon Disclosures. In Accounting Forum; Taylor \& Francis: Abingdon, UK, 2011; Volume 35, pp. 130-138.

22. Mata, C.; Fialho, A.; Eugénio, T. A decade of environmental accounting reporting: What we know? J. Clean. Prod. 2018, 198, 1198-1209. [CrossRef]

23. Cotter, J.; Najah, M.M. Institutional investor influence on global climate change disclosure practices. Aust. J. Manag. 2012, 37, 169-187. [CrossRef]

24. Schaltegger, S.; Csutora, M. Carbon accounting for sustainability and management. status quo and challenges. J. Clean. Prod. 2012, 36, 1-16. [CrossRef]

25. Coulson, A.; Adams, C.A.; Nugent, M.; Haynes, K. Exploring metaphors of capitals and the framing of multiple capitals: Challenges and opportunities for <IR>. Sustain. Account. Manag. Policy J. 2015, 6, 290-314. [CrossRef]

26. Grassmann, M.; Fuhrmann, S.; Guenther, T.W. Drivers of the disclosed connectivity of the capitals: Evidence from integrated reports. Sustain. Account. Manag. Policy J. 2019, 10, 877-908. [CrossRef]

27. Anselmsson, J.; Bondesson, N.V.; Johansson, U. Brand image and customers' willingness to pay a price premium for food brands. J. Prod. Brand Manag. 2014, 23, 90-102. [CrossRef]

28. Eccles, N.S. UN principles for responsible investment signatories and the anti-apartheid SRI movement: A thought experiment. J. Bus. Ethics 2010, 95, 415-424. [CrossRef]

29. Global Impact Investing Network (GIIN). Core Characteristics of Impact Invest. Available online: https://thegiin.org/assets / Core\%20Characteristics_webfile.pdf (accessed on 4 July 2020). 
30. Spiess-Knafl, W.; Scheck, B. Impact Investing: Instruments, Mechanisms and Actors; Palgrave Macmillan: London, UK, 2017.

31. Ben Abid, H. Impact Investing: Innovation or Rebranding? de Morais Sarmento, E., Herman, R.P., Eds.; Wiley: Hoboken, NJ, USA, 2020.

32. Equator Principles. The Equator Principles. Available online: https://equator-principles.com/wp-content/uploads/2020/05/ The-Equator-Principles-July-2020-v2.pdf (accessed on 13 August 2020).

33. Climate Bonds Initiative (CBI). 2019 Green Bond Market Summary; Climate Bonds Initiative (CBI): London, UK, 2020.

34. International Capital Market Association (ICMA). Sustainability Bond Guidelines; International Capital Market Association (ICMA): Zurich, Switzerland, 2018.

35. International Capital Market Association (ICMA). Sustainability-Linked Bond Principles. In Voluntary Process Guidelines; International Capital Market Association: Zurich, Switzerland, 2020.

36. Loan Market Association (LMA). Green Loan Principles; Loan Market Association (LMA): London, UK, 2018.

37. Loan Market Association (LMA). Sustainability Linked Loan Principles; Loan Market Association: London, UK, 2019.

38. EU Technical Expert Group on Sustainable Finance (TEG). Taxonomy: Final Report of the Technical Expert Group on Sustainable Finance; EU Technical Expert Group on Sustainable Finance: Brussels, Belgium, 2020.

39. Schmuck, D.; Matthes, J.; Naderer, B. Misleading consumers with green advertising? An affect-reason-involvement account of greenwashing effects in environmental advertising. J. Advert. 2018, 47, 127-154. [CrossRef]

40. Parguel, B.; Benoit-Moreau, F.; Russell, C.A. Can evoking nature in advertising mislead consumers? The power of executional greenwashing. Int. J. Advert. 2015, 34, 107-134. [CrossRef]

41. Baum, L.M. It's not easy being green. Or is it? A content analysis of environmental claims in magazine advertisements from the United States and United Kingdom. Environ. Commun. 2012, 6, 423-440. [CrossRef]

42. Delmas, M.A.; Burbano, V.C. The drivers of greenwashing. Calif. Manag. Rev. 2011, 54, 64-87. [CrossRef]

43. Zerbib, D.O. The effect of pro-environmental preferences on bond prices: Evidence from green bonds. J. Bank. Financ. 2019, 98, 39-60. [CrossRef]

44. Ansar, A.; Caldecott, B.; Tilbury, J. Stranded Assets and the Fossil Fuel Divestment Campaign: What Does Divestment Mean for the Valuation of Fossil Fuel Assets? University of Oxford: Oxford, UK, 2013.

45. Bataille, C. A review of technology and policy deep decarbonization pathway options for making energy-intensive industry production consistent with the Paris Agreement. J. Clean. Prod. 2018, 187, 960-973. [CrossRef]

46. Rozenberg, J.; Vogt-Schilb, A.; Hallegatte, S. Instrument choice and stranded assets in the transition to clean capital. J. Environ. Econ. Manag. 2020, 100, 1-29. [CrossRef]

47. Blacconiere, W.G.; Johnson, M.F.; Johnson, M.S. Stranded costs and competitive forces in the electric utility industry. J. Account. Audit. Financ. 1997, 12, 199-219. [CrossRef]

48. Farfan, J.; Breyer, C. Structural changes of global power generation capacity towards sustainability and the risk of stranded investments supported by a sustainability indicator. J. Clean. Prod. 2017, 141, 370-384. [CrossRef]

49. Kalkuhl, M.; Steckel, J.C.; Edenhofer, O. All or nothing: Climate policy when assets can become stranded. J. Environ. Econ. Manag. 2020, 100, 1-21. [CrossRef]

50. Park, A.; Ravenel, C. Integrating sustainability into capital markets: Bloomberg LP and ESG's quantitative legitimacy. J. Appl. Corp. Financ. 2013, 25, 62-67. [CrossRef]

51. Coglianese, C.; Starobin, S.M. Social science and the analysis of environmental policy. Rev. Policy Res. 2020, 37, 578-604. [CrossRef]

52. Bank of England. Breaking the Tragedy of the Horizon-Climate Change And Stability. Available online: https: / / www.bankofengland.co.uk/-/media/boe/files/speech/2015/breaking-the-tragedy-of-the-horizon-climate-change-andfinancial-stability.pdf?la=en\&hash=7C67E785651862457D99511147C7424FF5EA0C1A (accessed on 27 August 2020).

53. Bank for International Settlements (BIS). Central Banking and Financial Stability in the Age of Climate Change. In The Green Swan; Bank for International Settlements (BIS): Basel, Switzerland, 2020.

54. Pollitt, C. Wickedness will not wait: Climate change and public management research. Public Money Manag. 2015, 35, 181-186. [CrossRef]

55. Pollitt, C. Debate: Climate change-The ultimate wicked issue. Public Money Manag. 2016, 36, 78-80. [CrossRef]

56. Widerberg, O.; Pattberg, P. Accountability challenges in the transnational regime complex for climate change. Rev. Policy Res. 2017, 34, 68-87. [CrossRef] 